\title{
Factors Affecting Level of Satisfaction of Slack Application Usage in Supporting the Management of Digital Division of Service Division of PT Telekomunikasi Indonesia, Tbk.
}

\section{Mohammad Ridha and Aisyah Aprilea Suprayitno}

Office and Secretary Administration Study Program, Vocational Education Program, Universitas Indonesia

\section{Abstract}

This research focuses on the analysis of factors affecting level sastisfaction of Slack application usage in supporting the management of digital division of service division of PT Telekomunikasi Indonesia, Tbk. This research was conducted in PT Telekomunikasi Indonesia, Tbk, a state-owned company engaged in telecommunication services and network services in the territory of Indonesia. Its

Corresponding Author: Mohammad Ridha

Received: 8 June 2018 Accepted: 17 July 2018 Published: 8 August 2018

Publishing services provided by Knowledge

(c) Mohammad Ridha and Aisyah Aprilea Suprayitno. This article is distributed under the terms of the Creative Commons Attribution License, which permits unrestricted use and redistribution provided that the original author and source are credited.

Selection and Peer-review under the responsibility of the 2nd ICVHE Conference Committee. status as a State-owned Company whose shares are traded on the stock exchange, the majority shareholder of the Company is the Government of the Republic of Indonesia while the rest is controlled by the public. The research model consists of four dimensions of "Satisfaction Level of Slack Application by Affected Factors on Support Scheduling Agenda", namely: Qualities of Application, Qualities of Information, Human Resources, and Management Supporting. Slack is a cloud-based set of team collaboration tools and services, founded by Stewart Butterfield. Slack began as an internal tool used by their company. The name is an acronym for "Searchable Log of All Conversation and Knowledge". Quantitative method is used in this research with descriptive analysis to oversee the perception of employees digital service division of PT. Telekomunikasi Indonesia, Tbk. at their Head Office. The research method was using random sampling. Data were gathered through questionnaires on April 21st 30th 2017. The population were 100 employees, with a sample of 25 employees which using a convenience sampling technique.

Keywords: Slack, Level Satisfaction, PT. Telekomunikasi, Tbk, Telecomunication Services, Network Services, Schedulling Agenda

\section{Introduction}

\subsection{Background}

Recently launched an Ariane 5 rocket that airs from the Space Center Guiana Space Center on February 14, 2017, marking the start of the journey of Satellite duty to 
will escort the archipelago at the position of 118 degrees east longitude at an altitude of 35,755 kilometers above the Makassar Strait. This success marks 40 years of PT Telkom Indonesia (Persero) Tbk (Telkom) in the business and operation of satellite telecommunication for Indonesia.

The task of escorting the archipelago is a homework for every state-owned company in Indonesia to be able to compete. Thus the embodiment of the largest stateowned telecommunications company in Indonesia and Southeast Asia is very influentialin the world of telecommunications.

The Company / State-Owned Enterprise is partly owned by the state of $52.55 \%$; $47.45 \%$ by public. The shares are traded on BEI, NYSE, LSE and Public Offering Without Listings (POWL) in Japan. In accordance with the functions and roles of State Owned Enterprises or Indonesian state-owned companies which must meet the needs of economic goods and services that can not be provided by the private sector and can provide services to meet the needs of the community.

Along with the launch of the satellite is expected to reach all areas in Indonesia, Southeast Asia and parts of East Asia to get to the digital community. In accordance with the hope to lead the digital community then PT Telekomunikasi Indonesia in carrying out the company's activities also apply the system of digitalization is the process of media transfer of printed form, audio, and video into a form of computer information technology.

Therefore, people are required to be reactive to change. Similarly, with the secretarial activities of Digital Services Division of PT Telekomunikasi Indonesia. The field is one of the areas that play an important role in a corporate management. With the onset of the digital society era, the secretaria I itself in some companies has changed the name of the secretary to administrative assistant or Administrative Assistant. As for that every company has a division that performs the function. Thus, each company has its own way or path to perform the function of secretarial with the system adopted by the company. The secretarial functional activities of a company engaged in the field of communication networks will be different from other companies.Companies that rely on technological advances such as PT Telekomunikasi Indonesia certainly have a system to run functional from secretarial and could be secretarial digital version of the company that makes it different from others. In this discussion later, the level of Slack user satisfaction is influenced by certain factors so that applications used to support the digital era for digital companies will be optimal. With the use of Slack will be known how to integrate digital communication system to make secretarial activities 
in organizing and publishing agenda which includes 23 units in it and also accessed through website every day.

\section{Theory Framework}

\subsection{The basic concept of secretarial}

In the General Dictionary of Indonesian Language, the secretariat means work, all secretarial affairs, or may also mean a secretariat. The secretariat means the place of a secretary doing the work in the field of secretariat. According to Wursanto Secretariat means the place of secretaries and their staff to conduct activities in the field of secretariat or administration which includes all activities of the management of correspondence which starts from collecting (recording), recording, conducting, sending and storing all material information required by the organization.

According to Braum and Ramon in Saiman an expert from Portugal said that the notion of a secretary is an assistant of a head or a leader who receives dictation, prepares correspondence, accepts guests, examines or warns his head or chairman of his official obligations or agreements and performs many related obligations in order to increase the effectiveness of the head or his or her leadership on other related obligations to improve the effectiveness of the head or the leader.According to Dewi (2011) The agenda of leadership is an agenda that includes all the activities of leadership in it all appointments, meetings, meetings with relations and so forth. According to Sumarto (2009), the work agenda of the leadership is the leadership schedule which is compiled based on the timing of activities and promises that have been approved by the leadership.

According to Hendarto and Tulusharyono (2008), an agenda that records the activities of leadership meetings, and organizes leaders to make the most of their time. According Sedianingsih, et al (2010) function agenda work agenda used for appointment or appointment. Become a reminder that includes the place information, with whom, as well as some necessary information. Can make it easier to find relevant information and complete it with data that is important to know in writing the leadership agenda. 


\subsection{Basic concepts of communication}

According to Rogers \& 0. Lawrence Kincaid communication is an interaction where there are two or more people who are building or exchanging information with each other that will eventually arrive where they understand and understand each other.

As for some common characteristics of communication include the following:

1. Dynamic and sustainable

The point is that the process of giving and receiving information will continue unceasingly.

2. Functional and aiming

Communication helps people get what they want, help achieve goals or gain social cultivation. With human communication trying to adjust to their environment and make it something meaningful.

3. Be social

Communion is a vehicle used to test our observations and ideas with others. As human social beings need others. Through communication these needs are met.

4. Be complex

The communication process is not simple because it involves complex and difficult to predict human beings. Behavior, attitude, value orientation, perception, and human ideas are involved in the communication process.

In communication delivery of messages or any exchange of information there are various dimensions:

1. Verbal and Non-Verbal Communication

Verbal communication is a process of understanding exchange using words. While non-verbal communication is the process of delivering messages without using words, such as facial expressions, hand movements, body movements and so on.

2. One Way and Two Way Communication

Communication is emphasized on the message stream. One-way communication, messages flow only from message senders. While the other two-way communication message flowing both from the sender and receiver. In general, two-way communication shows better results than one-way communication.In the twoway communication occurs discussion between the sender of the message and 
the recipient of the message so that the recipient will feel satisfied because he felt involved.

\section{Research Metodology}

\subsection{Designing research methods}

This stage aims to design a model that is used in conducting research and define the variables used.

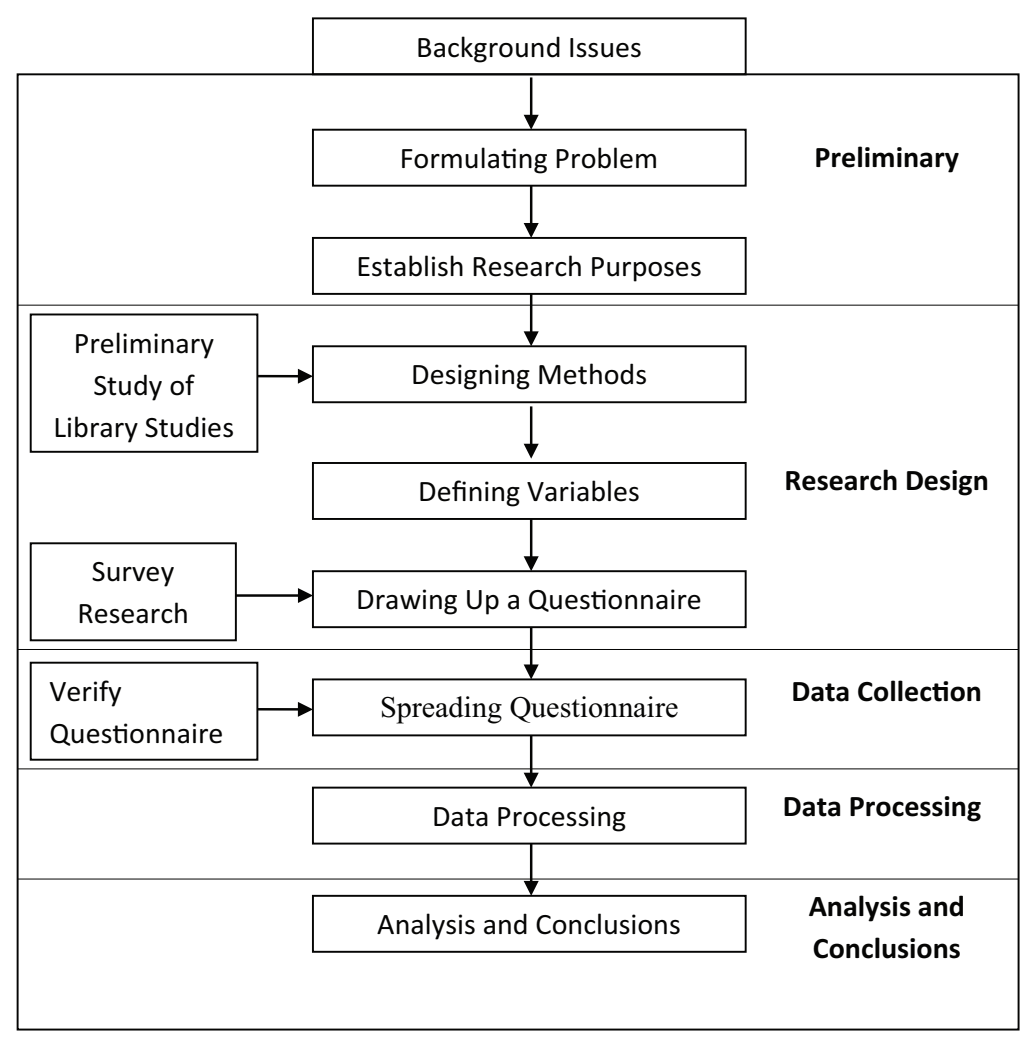

\subsection{Factors affecting level of satisfaction of application use in supporting work agenda management}




\subsubsection{Analysis model}

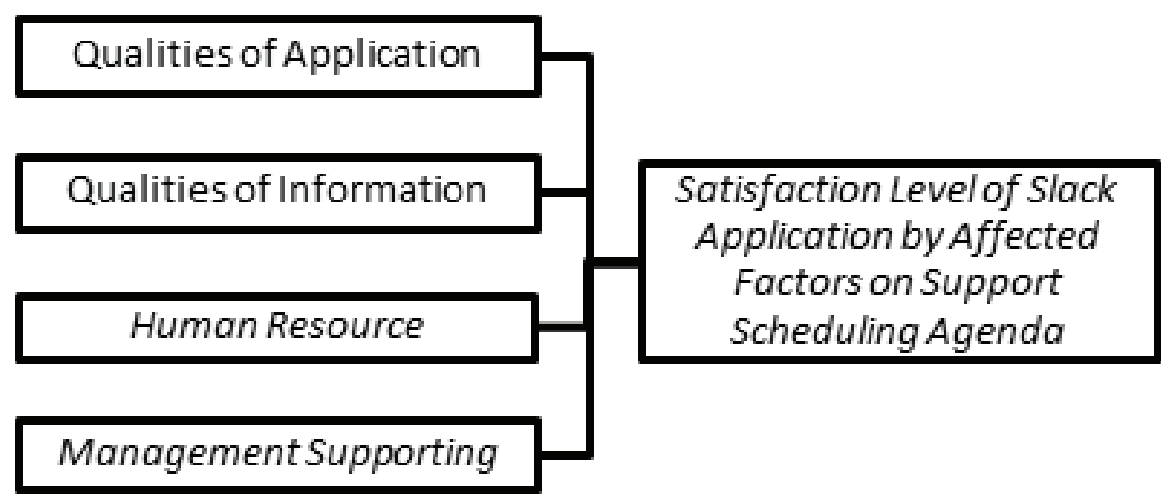

\subsubsection{Analysis used}

The research results of DeLone and McLean, Seddon and Kiew, DeLone and McLean, Wixon and Todd, and Zaied.

\subsection{Research variables}

After the model of Factors Affecting the Satisfaction Level of Slack Application Usage in Supporting the Management of DDS (Satisfaction Level of Slack Application by Affected Factors on Support Scheduling Agenda) agenda set, further derived the analytical variables used. These variables are attributes or items of each dimension. Elements or attributes that will be a benchmark in this analysis by asking questions about these attributes to the respondent. The following are the items or attributes:

\subsection{Research methods}

The sample used in this study is all users of Slack applications in the Digital Service Division. The number of sampling places in the field is about 100 users. Data obtained by sending questionnaires to the respondents that all users of Slack applications. Questionnaires were adopted from [4 ] with four Qualities of Application variables, Qualities of Information, Human Resource, Management Supporting and [1] one dependent variable Factors Affecting Level of Satisfaction of Slack Application Usage in Supporting 


\begin{tabular}{|c|c|c|}
\hline VARIABLE & NO & ATRIBUTES \\
\hline \multirow[t]{12}{*}{ Qualities of Application } & \multicolumn{2}{|r|}{ Flexibility } \\
\hline & 1 & Slack can be used by all agencies \\
\hline & \multicolumn{2}{|r|}{ Ease of Use } \\
\hline & 1 & $\begin{array}{l}\text { Error information is easily corrected with } \\
\text { Slack tools }\end{array}$ \\
\hline & \multicolumn{2}{|r|}{ Realibility } \\
\hline & 1 & $\begin{array}{l}\text { The company directs on the initial use of } \\
\text { Slack. }\end{array}$ \\
\hline & 2 & Users are skilled at using Slack. \\
\hline & \multicolumn{2}{|r|}{ Proof of real / portable device (tongibles) } \\
\hline & 1 & Facility to access Slack is adequate. \\
\hline & 2 & Sufficient internet network facility. \\
\hline & \multicolumn{2}{|r|}{ Effectiveness } \\
\hline & 1 & Features integrated with other social media. \\
\hline \multirow[t]{6}{*}{ Qualities of Information } & \multicolumn{2}{|r|}{ Relevance } \\
\hline & 1 & $\begin{array}{l}\text { The Slack feature can provide work agenda } \\
\text { information. }\end{array}$ \\
\hline & 2 & $\begin{array}{l}\text { Slack can meet the needs of Information and } \\
\text { communication in many directions }\end{array}$ \\
\hline & \multicolumn{2}{|r|}{ Accurate } \\
\hline & 1 & The work agenda is accurate. \\
\hline & 2 & $\begin{array}{l}\text { Schedule changes are identified and can be } \\
\text { trusted. }\end{array}$ \\
\hline \multirow[t]{3}{*}{ Human Resource } & \multicolumn{2}{|r|}{ Mastery of application } \\
\hline & 1 & Users know the general Slack function. \\
\hline & 2 & $\begin{array}{l}\text { Users know the function of each feature / } \\
\text { channel available on Slack DDS. }\end{array}$ \\
\hline \multirow[t]{2}{*}{ Management Supporting } & 1 & $\begin{array}{l}\text { In general, companies support Slack as a } \\
\text { means of many-way discussion forums. }\end{array}$ \\
\hline & 2 & $\begin{array}{l}\text { The company creates channels on Slack to } \\
\text { support discussion activities. }\end{array}$ \\
\hline
\end{tabular}

DDS Work Agenda Management (Satisfaction Level of Slack Application by Affected Factors on Support Scheduling Agenda).

The time limit specified for the distribution of questionnaires to the respondents until the return questionnaire is for 1 week, ie 21 April 2017 - 30 April 2017. Before the 
analysis, first tested the validity and reliability of the questionnaire. The making of the analysis aims to provide an interpretation of the correlation of questions from the processing of raw data and discuss the results. In the next section will also be given an analysis of the actions that need to be taken to determine the correlation between free variables using Slack in managing the work agenda.

\subsection{Data collection}

This small study uses a number of data on respondents' perceptions of the questionnaires distributed throughout the unit about the use of Slack in managing the DDS work agenda. The number of units in Digital Service Division (DDS) is 23 units. Sample research conducted to approach all existing units. So the units are used as a place to conduct research and the number of respondents taken is 25 respondents. The research tool used in this research is a list of questions (questionnaires) given to the respondents. The questionnaire is closed and open. The method used to collect data is a random sample method of Slack users.

\subsection{Data processing}

Stages of data processing in this study consists of 2 parts, namely:

1. Prepare Raw Data

2. Spearman Correlation Calculations

\subsection{Measurement of research variables}

From the questionnaires that have been collected through the first stage of test results of primary data in the form of values or numbers likert scale is 1 s.d. 5 meanings of the numbers are as follows:

\begin{tabular}{|c|c|c|c|c|c|}
\hline & 1 Figure & 2 Figure & 3 Figure & 4 Figure & 5 Figure \\
\hline
\end{tabular}

Data in the form of numbers are then tabulated in the form of individual matricesvariables of size $n \times p$, where $n$ is the number of respondents and $p$ is the number of variables.

1. Application Quality (Qualities of Application) 
These characteristics include: usability, reliability, ease of use, efficiency, maintenance, and portability.

2. Quality of Information (Qualities of Information)

Characteristics contained in it include relevance, reliability, completeness, timeliness, understandability, and verifiability.

3. Human Resource (Human Resource Responsiveness).

Users' technical capabilities can be measured by indicators including: the level of knowledge and mastery of applications, educational backgrounds, and user experience.

\section{Management Support (Management Supporting)}

Management support is measured by a user's positive attitude, user training opportunities and perceptions of top management attitudes.

\subsection{Analysis method}

According to Sekaran (2004), the use of better instruments will better ensure the accuracy of the results, which will ultimately improve the scientific quality of the research. Therefore, it is necessary to assess how good the measurement (goodness of measure) in this research. To measure goodness of measures used validity test, reliability test.

\subsection{Research results and discussion}

\subsubsection{Validity and reliability test}

The result of validity test shows that only 7 variable indicator used in this research have Internal Correlation value higher than 0.5 . Therefore, it can be said that the 7 indicators of such a variable are valid and the rest are not and must be eliminated.Reliability test results performed as much as 3 times. The first test reliability value in the column less than 0.497 is not valid against the question item so it must be removed invalid questions.

However, once tested again, the 13th question item is less than the table $r$ then it needs to be retested and item 13 must be omitted.The last reliability test results show that after eliminating $8+1$ questions and showing the variable still has a Cronbach's Alpha value higher than 0.851 , this value is compared with the r-table value, r-table 
TABLE 1: Table of Reliability Test I SPSS.

\begin{tabular}{|c|c|c|c|c|c|}
\hline \multicolumn{6}{|c|}{ Item-Total Statistics } \\
\hline & $\begin{array}{l}\text { Scale Mean if } \\
\text { Item Deleted }\end{array}$ & $\begin{array}{c}\text { Scale } \\
\text { Variance if } \\
\text { Item Deleted }\end{array}$ & $\begin{array}{l}\text { Corrected } \\
\text { Item-Total } \\
\text { Correlation }\end{array}$ & $\begin{array}{c}\text { Squared } \\
\text { Multiple } \\
\text { Correlation }\end{array}$ & $\begin{array}{c}\text { Cronbach's } \\
\text { Alpha if Item } \\
\text { Deleted }\end{array}$ \\
\hline VARoooo1 & 61.2500 & 34.867 & .415 & . & .760 \\
\hline VARooo02 & 62.3125 & 39.163 & -.212 & . & .805 \\
\hline VARoo003 & 62.2500 & 35.267 & .109 & . & .788 \\
\hline VARoooo4 & 61.8750 & 35.183 & .162 & . & .778 \\
\hline VARoo005 & 61.1875 & 33.896 & .588 & . & .751 \\
\hline VARoooo6 & 61.3750 & 31.850 & .653 & . & .739 \\
\hline VARooo07 & 61.1875 & 33.629 & .635 & . & .748 \\
\hline VARoooo8 & 61.2500 & 33.000 & .587 & . & .746 \\
\hline VARooo09 & 61.6250 & 32.117 & .536 & . & .746 \\
\hline VARoo010 & 61.7500 & 32.733 & .404 & . & .757 \\
\hline VARoo011 & 61.5000 & 32.400 & .617 & . & .743 \\
\hline VARoo012 & 61.5625 & 33.463 & .364 & . & .760 \\
\hline VARoo013 & 61.7500 & 32.733 & .527 & . & .748 \\
\hline VARooo14 & 61.8125 & 29.896 & .680 & . & .729 \\
\hline VARoo015 & 61.8750 & 32.517 & .320 & . & .767 \\
\hline VARoo016 & 61.6875 & 35.029 & .139 & . & .784 \\
\hline
\end{tabular}

with the formula $\mathrm{df}=\mathrm{n}-2 ; \mathrm{N}=16$ and alpha or a significance level of $5 \%$ or 0.5 ; The value is 0.497 . Therefore, it can be said that only 7 variable measurements used in this study are reliable.

In this study respondents were given one week. There are 16 respondents who returned the questionnaire and adjusted by the time limit specified. After going through the stages of validity and reliability, it affects the initial model used is the elimination of one independent variable that leaves three variables of the four previous free variables. Later, in the final stage of the questionnaire only includes 3 independent variables. 
TABLE 2: Table of Reliability Test III SPSS.

\begin{tabular}{|c|c|c|c|c|c|}
\hline \multicolumn{6}{|c|}{ Item-Total Statistics } \\
\hline & $\begin{array}{l}\text { Scale Mean if } \\
\text { Item Deleted }\end{array}$ & $\begin{array}{c}\text { Scale } \\
\text { Variance if } \\
\text { Item Deleted }\end{array}$ & $\begin{array}{l}\text { Corrected } \\
\text { Item-Total } \\
\text { Correlation }\end{array}$ & $\begin{array}{c}\text { Squared } \\
\text { Multiple } \\
\text { Correlation }\end{array}$ & $\begin{array}{l}\text { Cronbach's } \\
\text { Alpha if Item } \\
\text { Deleted }\end{array}$ \\
\hline VARoo005 & 29.7500 & 13.267 & .581 & .512 & .842 \\
\hline VARoooo6 & 29.9375 & 11.796 & .685 & .557 & .827 \\
\hline VARoo007 & 29.7500 & 13.133 & 619 & .660 & .839 \\
\hline VARoooo8 & 29.8125 & 12.829 & .544 & .721 & .843 \\
\hline VARoooo9 & 30.1875 & 11.763 & .594 & .652 & .839 \\
\hline VARooo11 & 30.0625 & 12.063 & .667 & .685 & .829 \\
\hline VARoo013 & 30.3125 & 12.629 & .488 & .623 & .851 \\
\hline VARooo14 & 30.3750 & 10.650 & .690 & .616 & .828 \\
\hline
\end{tabular}

TABLE 3: Table Croncabch's Alpha.

\begin{tabular}{|c|c|c|}
\hline \multicolumn{3}{|c|}{ Reliability Statistics } \\
\hline Cronbach's Alpha & $\begin{array}{c}\text { Cronbach's Alpha } \\
\text { Based on } \\
\text { Standardized } \\
\text { Items }\end{array}$ & $\mathrm{N}$ of Items \\
\hline .851 & .861 & 7 \\
\hline
\end{tabular}

\subsection{Results validity and reliability renew the model}

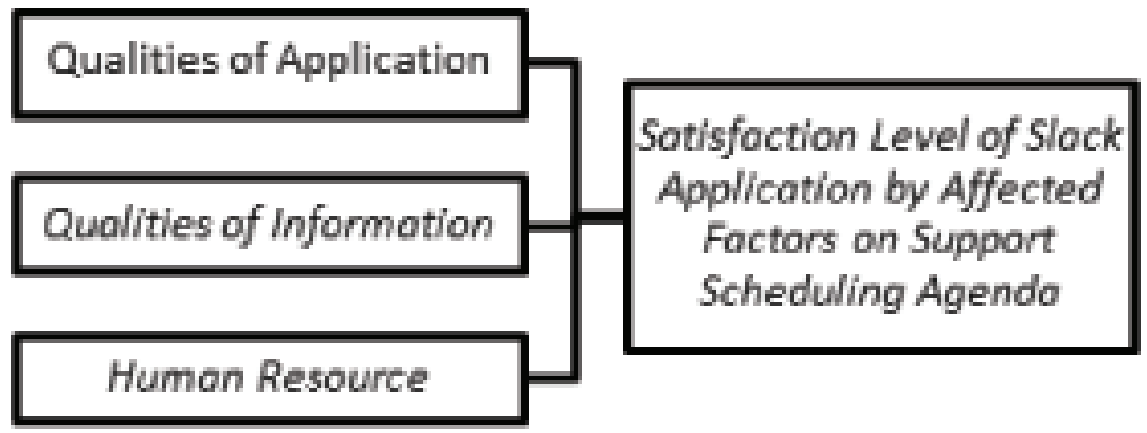

\section{Spearman correlation}

From the partial correlation test or Spearman Correlation the researcher did not find any correlation between questions, except in question 3 and question field or $P_{3}$ with 
TABLE 4: Variable Analysis Derived with updated model.

\begin{tabular}{|c|c|c|}
\hline VARIABLE & NO & ATRIBUTES \\
\hline \multirow[t]{5}{*}{ Qualities of Application } & \multicolumn{2}{|r|}{ Proof of real / portable device tangibles } \\
\hline & 1 & Facility to access Slack is adequate. \\
\hline & 2 & Sufficient internet network facility. \\
\hline & \multicolumn{2}{|r|}{ Effectiveness } \\
\hline & 1 & Features integrated with other social media. \\
\hline \multirow[t]{5}{*}{ Qualities of Information } & \multicolumn{2}{|r|}{ Relevance } \\
\hline & 1 & $\begin{array}{l}\text { The Slack feature can provide work agenda } \\
\text { information. }\end{array}$ \\
\hline & 2 & $\begin{array}{l}\text { Slack can meet the needs of Information and } \\
\text { communication in many directions }\end{array}$ \\
\hline & \multicolumn{2}{|r|}{ Accurate } \\
\hline & 1 & $\begin{array}{l}\text { Schedule changes are identified and can be } \\
\text { trusted. }\end{array}$ \\
\hline Human Resource & \multicolumn{2}{|r|}{ Mastery of Application } \\
\hline
\end{tabular}

P4. The grouping occurs after the Spearman Correlation process in SPSS. If the result between question one $\left(\mathrm{P}_{1}\right)$ with question two $\left(\mathrm{P}_{2}\right)$ in that column with sig (2-tailed) or 2 -way $>$ alpha because alpha used in the research is $5 \%$ then $p$-value $>$ alpha, then receive Ho.

If the data receives $\mathrm{Ho}$ or rho $=0$ or $\rho=0$ (no correlation), it can be concluded between the questions one $\left(\mathrm{P}_{1}\right)$ with question two $\left(\mathrm{P}_{2}\right)$ is uncorrelated. So also with every other question if searched korelasinya partially or one by one. However, in the third question field $\left(P_{3}\right)$ with the four questions ( $\left.P_{4}\right)$ and vice versa with the sig (2tailed) or 2-way <alfa's significance since the alpha used in the study is $5 \%$ then $p$ value $<$ alfa Reject Ho. If the data reject Ho or rho $\neq 0$ or $\neq \neq 0$ o (there is a correlation), it can be concluded three query columns ( $\left.\mathrm{P}_{3}\right)$ with four question lines ( $\left.\mathrm{P}_{4}\right)$ and also otherwise correlated

\section{Map distribution of respondents questionnaire results}

Based on the above data it can be stated that the variation of the answer starts at question 1-7 with the answer range partially filled from the range 2-5. Statement of 
TABLE 5: Nonparametric Correlations.

\begin{tabular}{|c|c|c|c|c|c|c|c|c|c|}
\hline \multicolumn{10}{|c|}{ Nonparametric Correlations } \\
\hline \multicolumn{10}{|l|}{ [DataSet1] } \\
\hline & & & & \multicolumn{2}{|c|}{ Correlations } & & & & \\
\hline & & & $P_{1}$ & $P_{2}$ & $P_{3}$ & $\mathrm{P}_{4}$ & $P_{5}$ & P6 & P7 \\
\hline \multirow[t]{21}{*}{ Spearman's rho } & $P_{1}$ & $\begin{array}{l}\text { Correlation } \\
\text { Coefficient }\end{array}$ & 1000 & 0.164 & -0.181 & -0.184 & -0.18 & 0.146 & 0.168 \\
\hline & & Sig (2-tailed) & & 0.434 & 0.386 & 0.377 & 0.39 & 0.488 & 0.423 \\
\hline & & $\mathrm{N}$ & 25 & 25 & 25 & 25 & 25 & 25 & 25 \\
\hline & & $\begin{array}{l}\text { Correlation } \\
\text { Coefficient }\end{array}$ & 0.164 & 1000 & 0.343 & 0.126 & -0.231 & 0.207 & 0.086 \\
\hline & & Sig (2-tailed) & 0.434 & & 0.094 & 0.549 & 0.268 & 0.322 & 0.684 \\
\hline & & $\mathrm{N}$ & 25 & 25 & 25 & 25 & 25 & 25 & 25 \\
\hline & & $\begin{array}{l}\text { Correlation } \\
\text { Coefficient }\end{array}$ & -0.181 & 0.343 & 1000 & 0.629 & 0.153 & 0.192 & 0.175 \\
\hline & & Sig (2-tailed) & 0.386 & 0.094 & & 0.001 & 0.467 & 0.357 & 0.403 \\
\hline & & $\mathrm{N}$ & 25 & 25 & 25 & 25 & 25 & 25 & 25 \\
\hline & & $\begin{array}{l}\text { Correlation } \\
\text { Coefficient }\end{array}$ & -0.184 & 0.126 & 0.629 & 1000 & 0.366 & -0.113 & 0.261 \\
\hline & & Sig (2-tailed) & 0.377 & 0.549 & 0.001 & & 0.072 & 0.591 & 0.208 \\
\hline & & $\mathrm{N}$ & 25 & 25 & 25 & 25 & 25 & 25 & 25 \\
\hline & & $\begin{array}{l}\text { Correlation } \\
\text { Coefficient }\end{array}$ & -0.18 & -0.231 & 0.153 & 0.366 & 1000 & -0.36 & 0.183 \\
\hline & & Sig (2-tailed) & 0.39 & 0.268 & 0.467 & 0.072 & & 0.864 & 0.382 \\
\hline & & $\mathrm{N}$ & 25 & 25 & 25 & 25 & 25 & 25 & 25 \\
\hline & & $\begin{array}{l}\text { Correlation } \\
\text { Coefficient }\end{array}$ & 0.146 & 0.207 & 0.192 & -0.113 & -0.036 & 1000 & 0.073 \\
\hline & & Sig (2-tailed) & 0.488 & 0.322 & 0.357 & 0.591 & 0.864 & & 0.73 \\
\hline & & $\mathrm{N}$ & 25 & 25 & 25 & 25 & 25 & 25 & 25 \\
\hline & & $\begin{array}{l}\text { Correlation } \\
\text { Coefficient }\end{array}$ & 0.168 & 0.086 & 0.175 & 0.261 & 0.183 & 0.073 & 1000 \\
\hline & & Sig (2-tailed) & 0.423 & 0.684 & 0.403 & 0.208 & 0.382 & 0.73 & \\
\hline & & $\mathrm{N}$ & 25 & 25 & 25 & 25 & 25 & 25 & 25 \\
\hline
\end{tabular}

Agreement stated for question number 1 as many as 9 respondents, which in which the question includes facility to access Slack and 16 respondents stated strongly agree. 


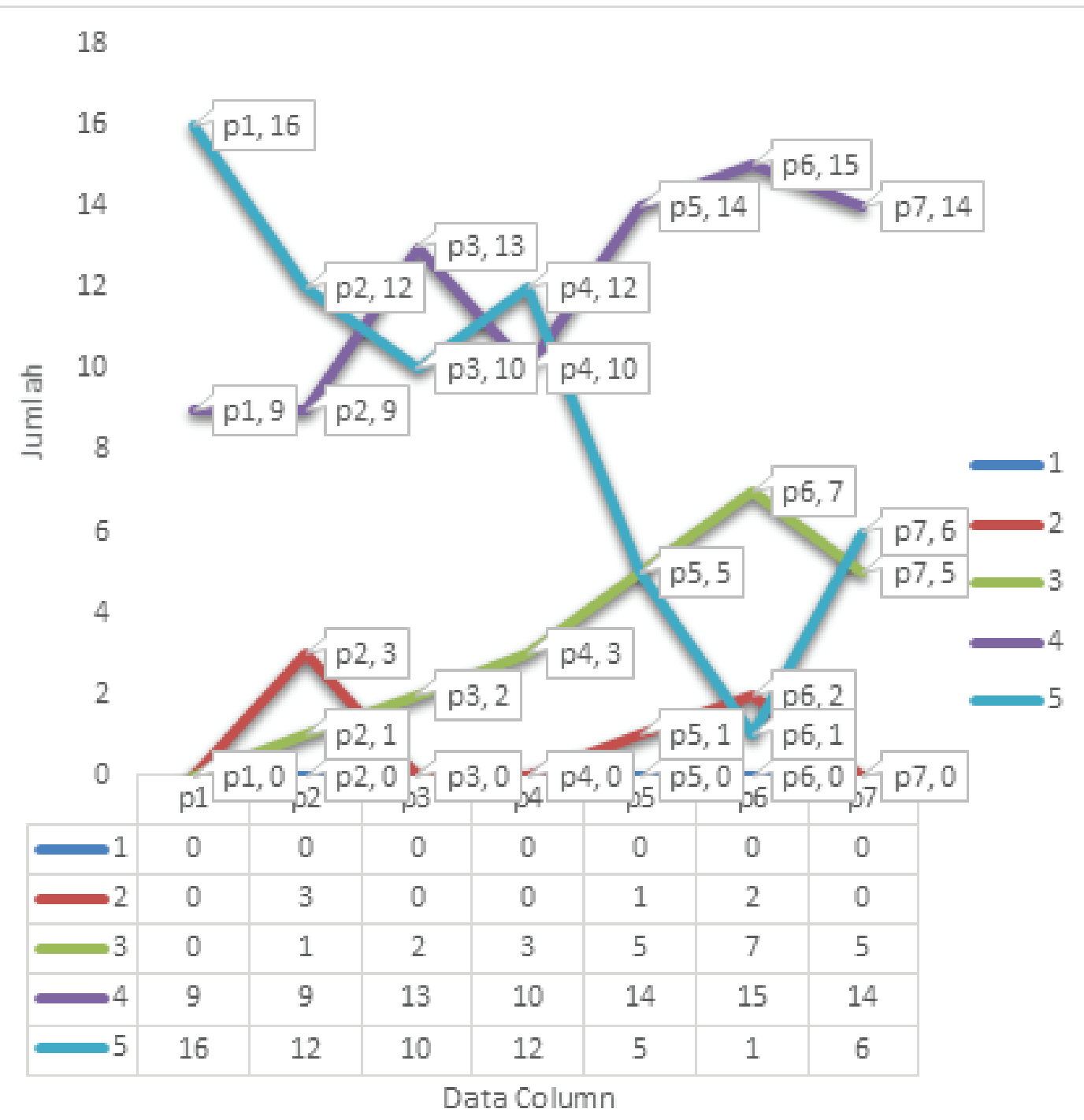

Figure 1: Descriptive Statistics of Research Variables.

Statement does not agree to answer question 2 as much as 3 respondents, hesitate as much as 1 respondent, agree as many as 9 respondents and strongly agree as many as 12 respondents, it includes adequate internet network to access Slack. Statement hesitate to answer question number 3 as much as 2 respondents, 13 respondents agreed and 10 respondents stated strongly agree. This includes the very effective integration of Slack with Google Calendar.

Statement hesitate to answer question number 4 as many as 3 respondents, 10 respondents agreed and 12 respondents stated strongly agree. This includes that the user knows the DDS work agenda by using very helpful Slack. Statements do not agree is shown on the answer to question 5 as much as 1 respondent, 5 respondents hesitate, 
14 respondents agree and 5 respondents strongly agree. It is about that communication or need discussion with other units can be reached by using Slack.

Statements do not agree is shown on the answer to question number 6 as much as 2 respondents, 7 respondents hesitate, 15 respondents agree and 1 respondent strongly agree. This includes a rapidly changing agenda change. Statements 5 respondents hesitated, 14 respondents agreed and 6 respondents strongly agree on question number 7. It is about human resources can know well the function of the channel on Slack.

\subsection{Interpretation}

1. Application Quality Variable

The free variable of Application Quality consists of 3 attributes, of the three attributes only one question that correlates to the attribute of Information Quality is the attribute of three $\left(\mathrm{P}_{3}\right)$ with attribute four $\left(\mathrm{P}_{4}\right)$. Positive correlation attribute of three with attribute 4 Quality of Information. The other two attributes do not correlate significantly with other free variables.

2. Variable Information Quality

The Information Quality Variable consists of 3 attributes and only 1 that correlates closely with the Information Quality attribute.

\section{Variable HR}

The Human Resources variable is not correlated anywhere with other independent variables.

\subsection{Analysis}

The correlations that occurred in the study only one, of the many after the number of attributes are eliminated during the stage of validity and reliability. It can be assumed that the basic satisfaction factor of the application is to integrate the google calender e-mail user account with Slack application. In accordance with the presence of Slack at this time is to provide team work and virtual team communication that supports high mobility without having any big obstacles.

Knowing the work agenda is a matter of concern as the secretariat division and the application provides the required function of management that is to make effective the DDS managemen t work agenda in a structured way. Not only automatically when 
the Google Calendar input on the agenda and then will appear alerts and notifications, but each agenda with the status cancelled, created, or updated.

In accordance with the estimation that this is a factor that strongly supports the existence of Slack in DDS management. When linking with real facts on the field on a daily basis, the agenda can be entered at any time through Google Calendar. However, before the turn of the day, there is an overall agenda release for the next day to see all the agenda is correct and nothing is missed or not input. This agenda release is not merely a release, but it can also see the agendary or leader's response to management when the agenda is unknown.Then, when asked about the dominant factors of this study is not concluded. The overall attributes of this study are independent variables in which no one is more dominant.

\section{Conclusions and Recommendations}

\subsection{Conclusion}

Correlation between variables with Spearman Correlation indicates a good correlation on free variable quality attribute application number three with free variable attribute quality attribute number four, and become an evaluation for strategy of increasing application usage in agenda management later. Researchers see the satisfaction of the use of the application is a reciprocal of the mature decision by management to meet the activities of the secretariat in terms of agenda management. The application is able to provide multi-way communication or team communication virtually with high mobility, the mobility in question is in terms of reaching the agenda information indefinitely and flexibly.

Another thing that does not correlate is not something that is considered to be failing, but it is not the most fundamental factor. Basically, the satisfaction of the use of the application is based on a thing that is perceived to fulfill the main purpose of the application usage.

\subsection{Recommendations}

Institutions can continue to innovate and follow the development of the digital world, as well as in the agenda management that has been integrated by Slack which is a present application for virtual team communication. It is accomplished by the use of Slack, with what researchers get during internships that what is used is what is needed 
today. If later that there will be applications that can provide more features than Slack it will be a consideration for management to switch.

The most important thing is the overall use of this application is one way of management to do secretarial things with appropriate corporate identity, corporate culture that must follow the development of the world of digitalization. A world that all things are usually done manually will switch by using digital devices to provide efficiency and effectiveness to an employment that takes place in office activities.

\section{References}

[1] Sutrisno, E. H. (2015). In E. H. Sutrisno, Budaya Organisasi (pp. 44-45). Jakarta: Prenadamedia Group.

[2] Creswell, J. (2015). RISET PENDIDIKAN Perencanaan, Pelaksanaan, dan Evaluasi Riset Kualitatif dan Kuantitatif. Yogyakarta: Pustaka Pelajar.

[3] Lawalata, C. F. (2012). Ponduan Lengkap Pekerjaan Sekretaris. Padang: @kademia Permata.

[4] Supardi. (2012). Aplikasi Statistika Dalam Penelitian. Jakarta: PT Ufuk Publishing House.

[5] 13 Pengertian Komunikasi Menurut Para Ahli Lengkap. (2017, 02 20). Retrieved from http://www.seputarpengetahuan.com/2015/03/100-macam-pengertiankomunikasi-menurut-para-ahli.html

[6] Hasan, T. (n.d.). Slack. Retrieved from http://aplikanologi.com/produktivitas/slackbikin-komunikasi-dalam-tim-makin-lancar/

[7] Kamal, F. (n.d.). Tinjauan Penanganan Agenda Kerja Pimpinan Pada Badan Kepegawaian Negara Jakarta. Retrieved from http://ejournal-binainsani.ac.id/index. php/JAKBI/article/download/17/16

[8] Mansfield, M. (2015, 12 22). What is Slack and How Do I Use It for My Team? . Retrieved from https://smallbiztrends.com/2015/12/slack-use-team.html

[9] Pengertian Sekretariat dan Kesekretariatan. (2017, 02 20). Retrieved from http:// www.ensikloblogia.com/2016/11/pengertian-sekretariat-sekretaris-dan.html

[10] Pengertian Sekretaris Menurut Definisi Para Ahli Adalah dan Jenisnya. (2017, 02 20). Retrieved from http://www.landasanteori.com: http://www.landasanteori.com/ 2015/07/pengertian-sekretaris-menurut-definisi.html 20 Febuari 2017

[11] Plimbi. (n.d.). Tips Menggunakan Aplikasi Chatting Slack untuk Mengelola Bisnis Anda. Retrieved from http://www.plimbi.com/article/158496/tips-menggunakanaplikasi-chatting-slack-untuk-men 
[12] Sugiana, Y. (2017, 02 20). "Peran dan Fungsi BUMN". Retrieved from Sridanti.com: Sridanti.com

[13] Nursudi, S. A. (2013). FAKTOR-FAKTOR YANG MEMPENGARUHI TINGKAT KEPUASAN PENGGUNA APLIKASI PELAPORAN KEUANGAN PEMERINTAH, 3-5.

[14] Rahadjo, D. P. (2017, 02 17). Satelit Telkom 3S Bermanuver Menjangkau Orbit Geostasioner". Retrieved from http://sains.kompas.com: http://sains.kompas. com/read/2017/02/17/12530061/satelit.telkom.3s.bermanuver.menjangkau.orbit. geostasioner pada tanggal 20 Februari 2017.

[15] Telkom Indonesia. (n.d.). Retrieved from http://www.telkom.co.id 